\title{
Lessons Learned? Comparing the Federal Reserve's Responses to the Crises of 1929-1933 and 2007-2009
}

\author{
David C. Wheelock
}

\begin{abstract}
The financial crisis of 2007-09 is widely viewed as the worst financial disruption since the Great Depression of 1929-33. However, the accompanying economic recession was mild compared with the Great Depression, though severe by postwar standards. Aggressive monetary, fiscal, and financial policies are widely credited with limiting the impact of the recent financial crisis on the broader economy. This article compares the Federal Reserve's responses to the financial crises of 1929-33 and 2007-09, focusing on the effects of the Fed's actions on the composition and size of the Fed balance sheet, the monetary base, and broader monetary aggregates. The Great Depression experience showed that central banks should respond aggressively to financial crises to prevent a collapse of the money stock and price level. The modern Fed appears to have learned this lesson; however, some critics argue that, in focusing on the allocation of credit, the Fed was too slow to increase the monetary base. The Fed's response to the financial crisis has raised new questions about the appropriate role of a lender of last resort and the long-run implications of actions that limit financial losses for individual firms and markets. (JEL E31, E32, E52, E58, N12)
\end{abstract}

Federal Reserve Bank of St. Louis Review, March/April 2010, 92(2), pp. 89-107.

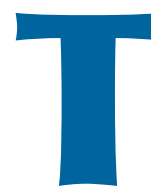

he financial crisis of 2007-09 is widely viewed as the worst financial disruption since the Great Depression of 1929-33. The banking crises of the Great Depression involved runs on banks by depositors, whereas the crisis of 2007-09 reflected panic in wholesale funding markets that left banks unable to roll over short-term debt. Although different in character, the crisis of 2007-09 was fundamentally a banking crisis like those of the Great Depression and many of the earlier crises that preceded large declines in economic activity (Gorton, 2009).

Table 1 reports information about every U.S. recession since the Great Depression of 1929-33more specifically, the periods designated as eco- nomic contractions by the National Bureau of Economic Research (NBER). The recent recession began in December 2007, according to the NBER. Although their Business Cycle Dating Committee has not officially identified the end of this recession, many economists believe that it ended in the middle of 2009; thus, the data used for this recession span December 2007 through June 2009.

In terms of duration, decline in real gross domestic product (GDP), and peak rate of unemployment, the recent recession ranks among the most severe of all postwar recessions. ${ }^{1}$ However,

1 The recession of 1945 was marked by a sharp, but short-lived decline in output as industries sharply reduced the production of war material at the end of World War II.

David C. Wheelock is a vice president and economist at the Federal Reserve Bank of St. Louis. The author thanks Michael Bordo, Bob Hetzel, Rajdeep Sengupta, and Dan Thornton for comments on a previous version of this article, which was presented at the conference "The History of Central Banking" at the Bank of Mexico on November 23, 2009. Craig P. Aubuchon provided research assistance.

(C) 2010, The Federal Reserve Bank of St. Louis. The views expressed in this article are those of the author(s) and do not necessarily reflect the views of the Federal Reserve System, the Board of Governors, or the regional Federal Reserve Banks. Articles may be reprinted, reproduced, published, distributed, displayed, and transmitted in their entirety if copyright notice, author name(s), and full citation are included. Abstracts, synopses, and other derivative works may be made only with prior written permission of the Federal Reserve Bank of St. Louis. 
Table 1

Key Macro Performance Measures Across U.S. Recessions

\begin{tabular}{lcccc} 
Recession & Duration (months) & $\begin{array}{c}\text { Real GDP: } \\
\text { Decline peak } \\
\text { to trough (\%) }\end{array}$ & $\begin{array}{c}\text { Unemployment: } \\
\text { Maximum value } \\
\text { during recession (\%) }\end{array}$ & $\begin{array}{c}\text { CPI: } \\
\text { Change peak } \\
\text { to trough (\%) }\end{array}$ \\
\hline $1929-33$ & 43 & -36.21 & 25.36 & -27.17 \\
$1937-38$ & 13 & -10.04 & 20.00 & -2.08 \\
$1945-45$ & 8 & -14.48 & 3.40 & 1.69 \\
$1948-49$ & 11 & -1.58 & 7.90 & -2.07 \\
$1953-54$ & 10 & -2.53 & 5.90 & 0.37 \\
$1957-58$ & 8 & -3.14 & 7.40 & 2.12 \\
$1960-61$ & 10 & -0.53 & 6.90 & 1.02 \\
$1969-70$ & 11 & -0.16 & 5.90 & 5.04 \\
$1973-75$ & 16 & -3.19 & 8.60 & 14.81 \\
1980 & 6 & -2.23 & 7.80 & 6.30 \\
$1981-82$ & 16 & -2.64 & 10.80 & 6.99 \\
$1990-91$ & 8 & -1.36 & 6.80 & 3.53 \\
2001 & 8 & 0.73 & 5.50 & 0.68 \\
$2007-09$ & $20 *$ & -3.66 & 9.50 &
\end{tabular}

*The current recession end date has not yet been determined by the NBER; data are through 2009:Q2.

the recent recession was mild compared with the economic declines of 1929-33 and 1937-38. For example, real GDP fell 36 percent during 1929-33, and the unemployment rate exceeded 25 percent. Moreover, the price level, measured by the consumer price index (CPI), fell by 27 percent. By contrast, the CPI rose 2.76 percent between December 2007 and June 2009.

Monetary, fiscal, and financial policies are widely credited for limiting the impact of the financial crisis of 2007-09 on the broader economy. In nominating Ben Bernanke for a second term as chairman of the Board of Governors of the Federal Reserve System, President Obama credited Bernanke with helping to prevent an economic freefall. ${ }^{2}$ Chairman Bernanke (2009c) has also cited "aggressive" policies for insulating the global economy, to some extent, from the financial crisis.

2 The White House press release (www.whitehouse.gov/the press office/Remarks-By-The-President-and-Ben-Bernanke-at-theNomination-of-Ben-Bernanke-For-Chairman-Of-the-FederalReserve/) provides the text of the president and Bernanke's remarks.
Bernanke noted that, in contrast, monetary policy was "largely passive" during the Great Depression.

This article summarizes the Federal Reserve's response to the financial crisis of 2007-09 and compares it with the Fed's response to financial shocks during the Great Depression. First, the article describes the Fed's actions as the recent crisis evolved. Initially, the Fed focused on making funds available to banks and other financial institutions, but used open market operations to prevent lending to individual firms from increasing total banking system reserves or the monetary base. As the crisis intensified, the Fed drew on authority granted during the Depression to provide emergency loans to distressed nonbank firms. The Fed also lowered its target for the federal funds rate effectively to zero and eventually purchased large amounts of U.S. Treasury and agency debt and mortgage-backed securities. The article shows the effects of these actions on the Fed's balance sheet, the monetary base, and broader monetary aggregates. 
The Fed was considerably less responsive to the financial crises of 1929-33. It neither lent significantly to distressed banks nor increased the monetary base sufficiently to arrest declines in the money stock and price level. The article discusses alternative explanations for the Fed's failure to pursue a more aggressive policy during the Great Depression. It also examines the impact of the Fed's doubling of reserve requirements in 1936-37, when officials feared that a large increase in excess reserves posed a significant inflation threat.

The next section summarizes the Fed's response to the crisis of 2007-09 and examines its impact on the composition and size of the System's balance sheet, the monetary base, and the growth of broader monetary aggregates. Subsequently, the article describes the Fed's actions in response to the financial shocks of the Great Depression, again focusing on the effects of the Fed's actions on the monetary base and broader monetary aggregates. Finally, the article compares the Fed's responses to the crises of 2007-09 and 1929-33 and highlights mistakes made during the Great Depression that the Fed did not repeat during the recent crisis.

\section{THE FED'S RESPONSE TO THE CRISIS OF 2007-09}

\section{The Initial Phase: August 2007-February 2008}

The recent financial crisis began with the downturn in U.S. residential real estate markets. Beginning in early 2007, a growing number of banks and hedge funds reported substantial losses on subprime mortgages and mortgage-backed securities, many of which were downgraded by credit rating agencies. The crisis first appeared in interbank lending markets in early August, when the London Interbank Offered Rate (LIBOR) and other funding rates spiked after the French bank BNP Paribas announced that it was halting redemptions for three of its investment funds (Brunnermeier, 2009). The Federal Reserve sought to calm markets by announcing on August 10 that "the Federal Reserve is providing liquidity to facilitate the orderly functioning of financial markets" and noting that, "as always, the discount window is avail- able as a source of funding” (Board of Governors [BOG], 2007). Subsequently, on August 17, the Board of Governors voted to reduce the primary credit rate by 50 basis points and to extend the maximum term of discount window loans to 30 days. Then, in September, the Federal Open Market Committee (FOMC) lowered its target for the federal funds rate in the first of many cuts that took the rate essentially to zero by December $2008 .^{3}$

Financial strains eased somewhat in September and October 2007 but reappeared in November. On December 12, the Federal Reserve announced the establishment of reciprocal currency agreements ("swap lines") with the European Central Bank and Swiss National Bank to provide a source of dollar funding in European financial markets. Over the next 10 months, the Fed established swap lines with a total of 14 central banks.

On December 12, the Fed also announced the creation of the Term Auction Facility (TAF) to lend funds directly to banks for a fixed term. The Fed established the TAF in part because the volume of discount window borrowing had remained low despite persistent stress in interbank funding markets, apparently because of a perceived stigma associated with borrowing at the discount window. Because of its anonymity, the TAF offered a source of term funds without any of the associated stigma. ${ }^{4}$ As of December 28, 2009, the Fed had provided $\$ 3.48$ trillion of reserves through TAF auctions.

\section{Rescue Operations, March-August 2008}

Financial markets remained unusually strained in early 2008. In March, the Federal Reserve established the Term Securities Lending Facility (TSLF) to provide secured loans of Treasury securities to primary dealers for 28-day terms. ${ }^{5}$ Later in March, the Fed established the

3 The St. Louis Fed provides a timeline of Federal Reserve and other official actions in response to the financial crisis (http://timeline.stlouisfed.org/index.cfm?p=home).

4 The Fed's website (www.federalreserve.gov/monetarypolicy/bst.htm) describes the TAF and other credit and liquidity programs instituted since 2007.

5 Primary dealers are banks and securities broker-dealers that trade U.S. government securities with the Federal Reserve Bank of New York on behalf of the Federal Reserve System. As of February 17, 2010, there were 18 primary dealers (www.newyorkfed.org/aboutthefed/fedpoint/fed02.html). 
Primary Dealer Credit Facility (PDCF) to provide fully secured overnight loans to primary dealers. The PDCF, a temporary facility, expired on February 1, 2010.

Because not all primary dealers are depository institutions, the Fed invoked authority under Section 13(3) of the Federal Reserve Act, which permits the Federal Reserve to lend to any individual, partnership, or corporation "in unusual and exigent circumstances" if the borrower is "unable to secure adequate credit accommodations from other banking institutions." Such loans must be "secured to the satisfaction of the [lending] Federal Reserve Bank."6 Section 13(3) was written into the Federal Reserve Act in July 1932 (and amended by the Banking Act of 1935 and Federal Deposit Insurance Corporation Improvement Act of 1991) out of concern that widespread bank failures had made it difficult or impossible for many firms to obtain loans, which depressed economic activity. ${ }^{7}$ The Fed made 123 loans totaling a mere $\$ 1.5$ million in the four years after the section was added to the Federal Reserve Act in 1932. ${ }^{8}$ Section 13(3) was not used again until 2008, when it became an important tool in the Fed's effort to limit the financial crisis.

Shortly after Section 13(3) was used to create the PDCF, the Federal Reserve Board again invoked Section 13(3) when it authorized the Federal Reserve Bank of New York to lend \$29 billion to a newly created limited liability corporation (Maiden Lane, LLC) to facilitate the acquisition of the distressed investment bank Bear Stearns by JPMorgan Chase. Bear Stearns was heavily invested in residential mortgage-backed securities, highly leveraged, and relied extensively on overnight loans to fund its investments. Bear Stearns faced imminent failure when the firm's creditors suddenly refused to continue to provide funding

\footnotetext{
6 See "Federal Reserve Act-Section 13: Powers of Reserve Banks" (www.federalreserve.gov/aboutthefed/section13.htm) for the text of this section.

7 Bernanke (1983) argues that bank failures increased the cost of credit intermediation during the Depression and shows that bank failures help explain the decline in economic activity.

8 See Fettig (2008) for a short history of Section 13(3) and Federal Reserve lending to non-bank firms or see Hackley (1973) for a more detailed history of Section 13(3) and other lending programs.
}

(Brunnermeier, 2009). Because of Bear Stearns' large size and interconnections with other large financial institutions through derivatives trading and loans, the Federal Reserve determined that "allowing Bear Stearns to fail so abruptly at a time when the financial markets were already under considerable stress would likely have had extremely adverse implications for the financial system and for the broader economy" (Bernanke, 2008a). ${ }^{9}$

The PDCF_-and especially the Maiden Lane loan-marked significant departures from the Fed's usual practice of lending only to financially sound depository institutions against good collateral. ${ }^{10}$ Former Federal Reserve Chairman Paul Volcker (2008) contends that the Fed's financial support for the acquisition of Bear Stearns by JPMorgan Chase tested "the time-honored central bank mantra in time of crisis: 'lend freely at high rates against good collateral'...to the point of no return." Certainly nothing like this support was provided or even contemplated by the Fed during the Great Depression. ${ }^{11}$

In July 2008, the Federal Reserve Board once again authorized loans to non-bank financial firms when it granted the Federal Reserve Bank of New York authority to lend to the Federal National Mortgage Association (Fannie Mae) and the Federal Home Loan Mortgage Corporation (Freddie Mac) if necessary to supplement attempts

\footnotetext{
9 Maiden Lane acquired $\$ 30$ billion (face value) of mortgage instruments from Bear Stearns. JPMorgan Chase provided a $\$ 1$ billion loan to Maiden Lane and agreed to take the first $\$ 1$ billion of any losses on its portfolio. As of January 7, 2010, the net portfolio holdings of Maiden Lane were valued at $\$ 26.7$ billion, and the outstanding principal amount of the Federal Reserve Bank of New York loan to Maiden Lane was $\$ 28.8$ billion (data source: Federal Reserve Statistical Release H.4.1, Factors Affecting Reserve Balances, Table 4; www.federalreserve.gov/releases/h41/Current/).

${ }^{10}$ Schwartz (1992), however, notes that the Fed made sizable discount window loans to both Franklin National Bank and Continental Illinois Bank before their failures in 1974 and 1984, respectively, as well as to many smaller banks that bank supervisors had identified as being in weak financial condition. The Federal Deposit Insurance Corporation Improvement Act of 1991 sought to limit discount window borrowing by failing banks.

${ }^{11}$ However, following the stock market crash in 1929, the Federal Reserve Bank of New York extended loans to New York City banks to enable them to absorb stock market loans held by securities firms. The Fed also offered support through commercial banks to issuers of commercial paper following the failure of Penn Central
} Corporation in 1970 (Schwartz, 1992). 
by the U.S. Department of the Treasury to stabilize those firms. The Fed was not called on to lend to either firm, however, and the Treasury Department placed both Fannie Mae and Freddie Mac under conservatorship in September 2008.

\section{Rescue Operations, September 2008- May 2009}

The financial crisis intensified during the final four months of 2008. Lehman Brothers, a major investment bank, filed for bankruptcy on September 15 after the failure of efforts coordinated by the Fed and Treasury Department to find a buyer for the firm. Subsequently, the Fed has been widely criticized for not rescuing Lehman Brothers. Allan Meltzer (2009), for example, argues that allowing Lehman Brothers to fail was "a major error" that "deepened and lengthened the current deep recession" (Meltzer, 2009a,b). Chairman Bernanke (2008b), however, has stated that "the troubles at Lehman had been well known for some time, and investors clearly recognized...that the failure of the firm was a significant possibility. Thus, we judged that investors and counterparties had time to take precautionary measures." Furthermore, by law, the Federal Reserve is not permitted to make unsecured loans and, according to Chairman Bernanke (2009c), the available collateral at Lehman Brothers "fell well short of the amount needed to secure a Federal Reserve loan of sufficient size to meet [the firm's] funding needs." Hence, the firm's failure was unavoidable (Bernanke, 2009c). Nonetheless, Chairman Bernanke has also stated that "Lehman proved that you cannot let a large internationally active firm fail in the middle of a financial crisis" (CBS News, 2009).

Within hours of the Lehman bankruptcy, the Fed was forced to confront the possible failure of American International Group (AIG), a large financial conglomerate with enormous exposure to subprime mortgage markets through the underwriting of credit default insurance and other derivative contracts and portfolio holdings of mortgagebacked securities. Fed officials determined that "in current circumstances, a disorderly failure of AIG could add to already significant levels of financial market fragility and lead to substantially higher borrowing costs, reduced household wealth, and materially weaker economic performance" (BOG, 2008a). Hence, on September 16 the Fed again invoked Section 13(3) of the Federal Reserve Act and made an $\$ 85$ billion loan to AIG, secured by the assets of AIG and its subsidiaries. Thus, in the span of two days, the Fed confronted the failure of two major financial firms. Neither firm was a depository institution and thus could not obtain support through the Fed's normal lending programs. In the case of Lehman Brothers, Federal Reserve officials determined that they could not prevent the firm's failure and concentrated on trying to limit the impact on other financial firms and markets. However, in the case of AIG, Fed officials determined that a rescue of the firm was necessary to protect the financial system and broader economy, and they therefore called on emergency lending authority granted under Section 13(3).

The Lehman bankruptcy produced immediate fallout. On September 16, the Reserve Primary Money Fund announced that the net asset value of its shares had fallen below $\$ 1$ because of losses incurred on the fund's holdings of Lehman commercial paper and medium-term notes. The announcement triggered widespread withdrawals from other money funds, which prompted the U.S. Treasury Department to announce a temporary program to guarantee investments in participating money market mutual funds. The Federal Reserve responded to the runs on money funds by establishing the Asset-Backed Commercial Paper Money Market Mutual Fund Liquidity Facility (AMLF) to extend non-recourse loans to U.S. depository institutions and bank holding companies to finance purchases of asset-backed commercial paper from money market mutual funds. ${ }^{12}$ Again, the Fed drew on its Section 13(3) authority (BOG, 2008b).

To help stabilize the financial system, on September 21, the Fed approved the applications of Goldman Sachs and Morgan Stanley to become

\footnotetext{
${ }^{12}$ A non-recourse loan is ultimately guaranteed only by the collateral pledged for the loan. Should a borrower default on an AMLF loan, the Federal Reserve could seize the asset-backed commercial paper pledged as collateral for the loan, but not other assets of the borrower.
} 
bank holding companies and authorized the Federal Reserve Bank of New York to extend credit to the U.S. broker-dealer subsidiaries of both firms, as well as to Merrill Lynch (BOG, 2008c). A few days later, the Fed increased its existing swap lines with the European Central Bank and several other central banks to supply additional dollar liquidity in international money markets.

Financial markets remained in turmoil over the ensuing weeks. To help alleviate financial strains in the commercial paper market, the Fed established the Commercial Paper Funding Facility (CPFF) on October 7. This facility provided financing for a special-purpose vehicle established to purchase 3-month unsecured and asset-backed commercial paper directly from eligible issuers. Once again, the Fed relied on Section 13(3) as the legal basis for establishing the CPFF, just as it did on October 21, when it created the Money Market Investor Funding Facility (MMIFF). Under the MMIFF, the Fed offered to provide loans to a series of special-purpose vehicles that purchase assets from money market mutual funds and other eligible investors (BOG, 2008d,e).

The Fed's next rescue operation came in November, when it participated with the Treasury Department and Federal Deposit Insurance Corporation in a financial assistance package for Citigroup. The Federal Reserve agreed, if necessary, to provide a non-recourse loan to support a federal government guarantee of some $\$ 300$ billion of real estate loans and securities held by Citigroup (BOG, 2008f). To date, the Federal Reserve has not been called on to make a loan under this agreement.

Two days later, on November 25, the Federal Reserve again invoked Section 13(3) of the Federal Reserve Act when it announced the creation of the Term Asset-Backed Securities Lending Facility (TALF). Under this facility, the Federal Reserve Bank of New York provides loans on a nonrecourse basis to holders of AAA-rated assetbacked securities and recently originated consumer and small business loans (BOG, 2008g). The TALF was launched on March 3, 2009, and the types of eligible collateral for TALF loans were subsequently expanded on March 19 and May 19, 2009. ${ }^{13}$
Throughout the fall of 2008, the Federal Reserve Board approved the applications of several large financial firms to become bank holding companies; these firms included Goldman Sachs, Morgan Stanley, American Express, CIT, and GMAC. The Board cited "unusual and exigent circumstances affecting the financial markets" for expeditious action on several of these applications. As bank holding companies, these firms are subject to Federal Reserve oversight and regulation, but they benefit from additional funding sources (chiefly deposits) and access to the Fed's discount window programs.

In addition to the Fed's rescue operations and programs to stabilize specific financial markets, the FOMC reduced its target for the federal funds rate in a series of moves that lowered the target rate from 5.25 percent in August 2007 to a range of 0 to 0.25 percent in December 2008 . On November 25, 2008, the FOMC announced its intention to purchase large amounts of U.S. Treasury securities and mortgage-backed securities issued by Fannie Mae, Freddie Mac, and the Government National Mortgage Association (Ginnie Mae). The FOMC increased the amount of its purchases in 2009. The stated purpose of the purchases of mortgage-backed securities was to reduce the cost and increase the availability of credit for the purchase of houses (BOG, 2008g). The move to support a particular market through open market purchases is highly unusual for the Federal Reserve and unprecedented on this scale since before World War II. ${ }^{14}$

\section{The Impact of Fed Actions on Monetary Aggregates}

The Fed's actions in 2007-09 resulted in large changes in, first, the composition and, ultimately, the size of the Federal Reserve's balance sheet. Figure 1 shows the changes in the volume and

\footnotetext{
13 See "Term Asset-Backed Securities Loan Facility" (www.federalreserve.gov/monetarypolicy/talf.htm) for details about the TALF program.

${ }^{14}$ Before the mid-1930s, the Federal Reserve Banks routinely purchased bankers' acceptances ("bills") in the open market. The Fed's founders sought to promote the use of the dollar and U.S. financial markets for the financing of international trade by creating an active acceptance market. Federal Reserve Banks set the interest rates ("bill buying rates") at which they would purchase acceptances and purchased the quantities that were offered at those rates.
} 


\section{Figure 1}

\section{Composition of Federal Reserve Assets}

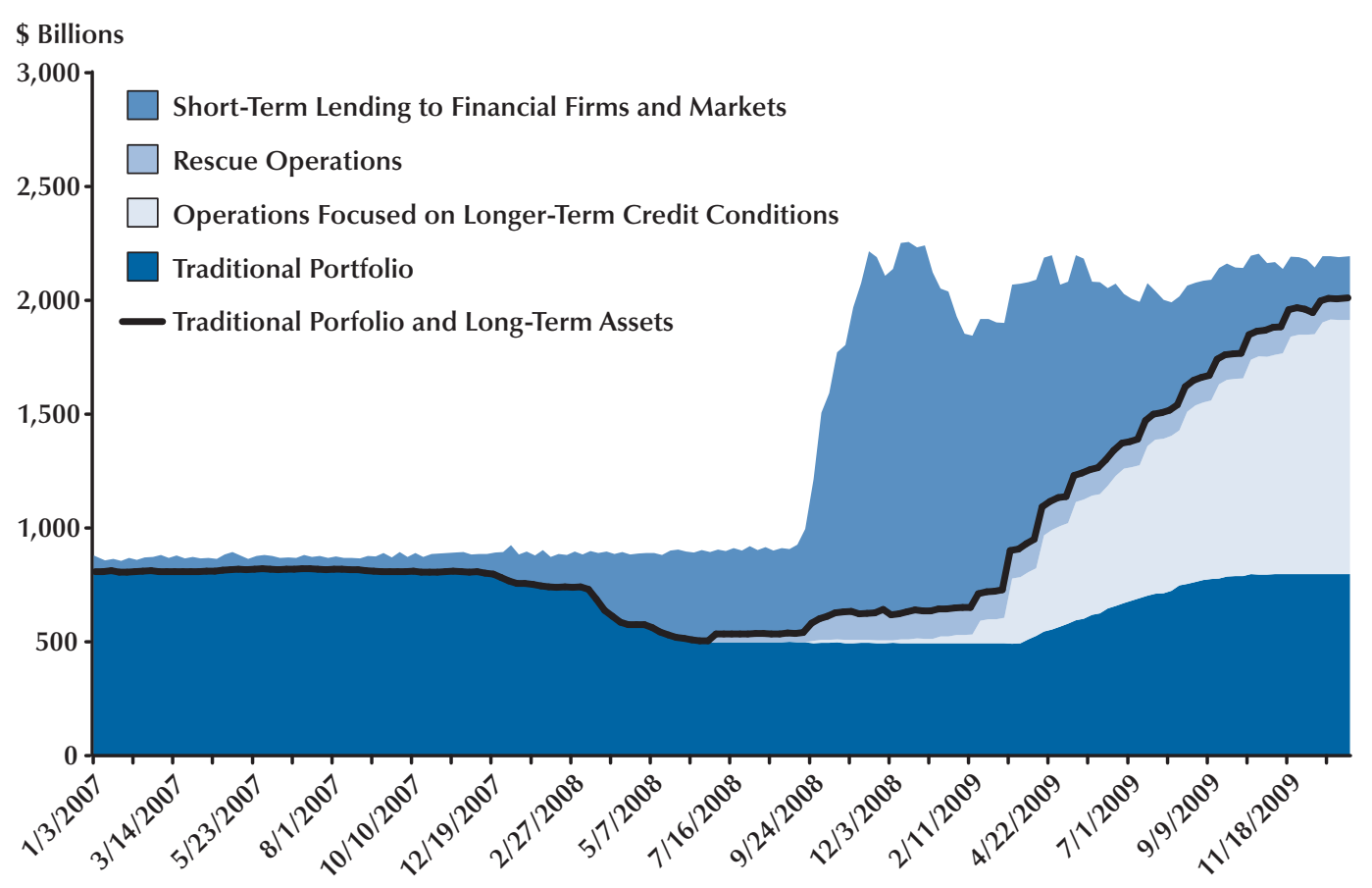

SOURCE: Federal Reserve H.4.1 Balance Sheet.

composition of Federal Reserve assets since the beginning of 2007. The share of the Fed's assets composed of loans and securities other than those issued by the Treasury began to rise in August 2007, when the financial crisis first appeared in interbank funding markets and the Fed eased terms for discount window loans. However, the overall size of the Fed's balance sheet remained roughly constant until September 2008 because the Fed offset (or "sterilized") increases in loans with open market sales of Treasury securities. ${ }^{15}$

The Federal Reserve was unable (and perhaps unwilling) to sterilize the large increase in its lending to financial institutions that occurred when the financial crisis intensified in September 2008. Loans to AIG in September 2008 and the introduction of the CPFF, AMLF, and increased swap lines with foreign central banks in September and

${ }^{15}$ The increase in Fed lending was also partly offset by an increase in U.S. Treasury deposit balances with Federal Reserve Banks.
October 2008 all resulted in a large increase in Federal Reserve credit outstanding.

The Fed's total assets reached a peak in the second week of December 2008 and began to fall as the strain in the financial markets eased and the volume of Federal Reserve credit extended through the CPFF, AMLF, and swap lines declined. Total assets began to rise again in the second quarter of 2009, however, when the Federal Reserve began to purchase Treasury and agency securities and mortgage-backed securities and the TALF was introduced. Federal Reserve lending to financial firms and markets remained high through September 2009, but became a smaller portion of the Fed's total assets when the Fed's holdings of Treasury and agency debt and other long-term assets, such as mortgage-backed securities and TALF loans, began to rise.

Figure 2 shows the relationship between the size of the Fed's balance sheet and the monetary 
Figure 2

\section{Federal Reserve Assets and the Monetary Base (2007-09)}

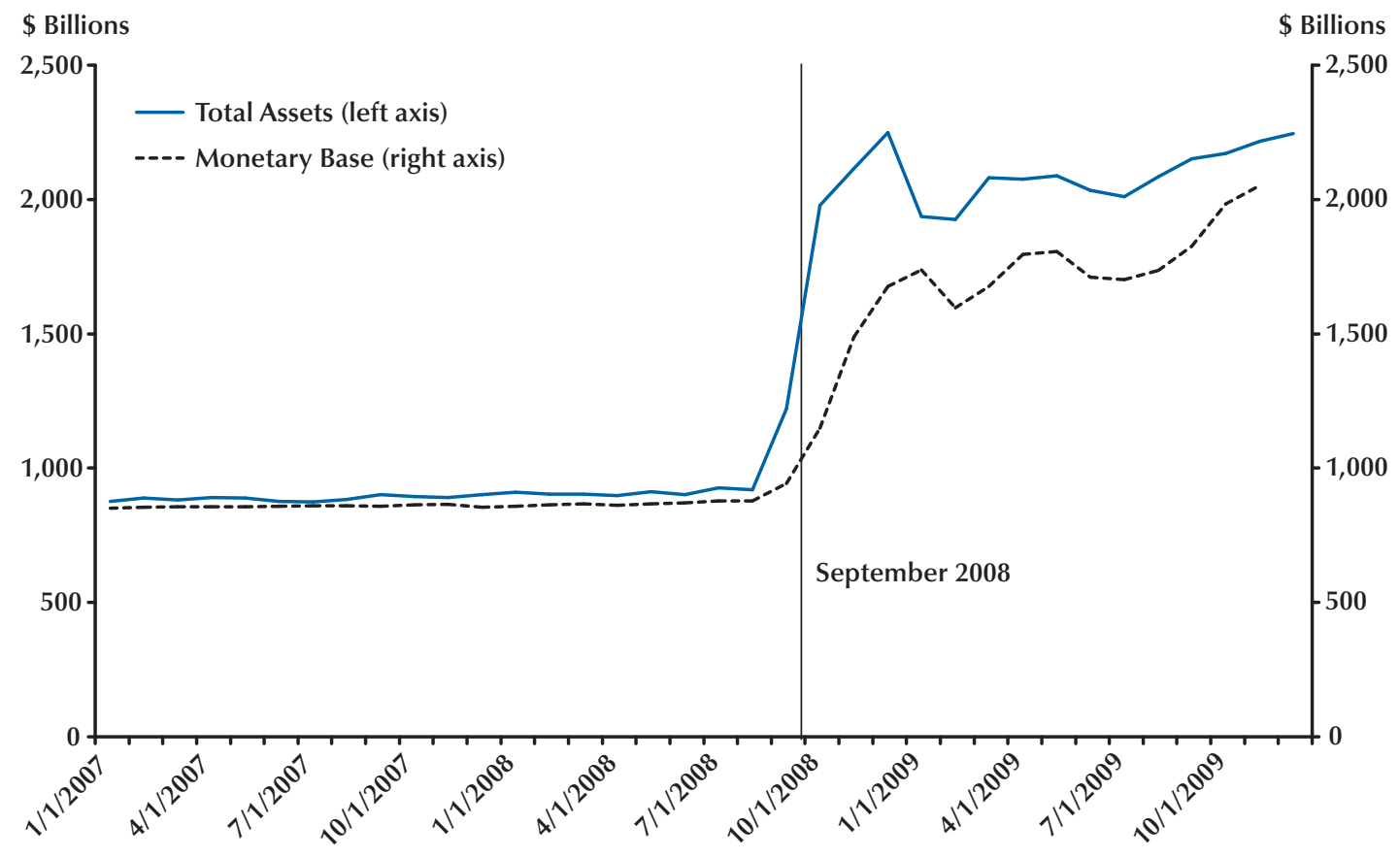

base, which consists of currency in circulation and the reserves held by depository institutions. ${ }^{16}$ As the figure shows, the monetary base was relatively constant until September 2008, when the Fed stopped using open market sales to prevent its lending to banks and other financial firms from increasing the System's total assets. Figure 3 shows that the growth rate of the M2 monetary aggregate also increased sharply in the fourth quarter of 2008 and remained correlated with monetary base growth throughout 2009.

Chairman Bernanke (2009a) has described the Fed's response to the financial crisis as "credit easing" to distinguish the policy from the "quantitative easing" approach that Japan and some other countries have at times adopted. Unlike a pure

\footnotetext{
${ }^{16}$ Figure 2 shows the St. Louis Adjusted Monetary Base, which is a measure of the base that is adjusted for changes in reserve requirements over time. Other measures of the monetary base, including unadjusted measures, show essentially the same relationship with the Federal Reserve balance sheet. These data are available from the Federal Reserve Bank of St. Louis (http://research.stlouisfed.org/fred2/).
}

quantitative easing policy, which targets the growth of the monetary base or a similar narrow monetary aggregate, the Fed's credit-easing policy was at least as much concerned with the allocation of credit supplied by the Fed to the financial system as with the quantity. Indeed, before September 2008, the Fed focused exclusively on reallocating an essentially fixed supply of Federal Reserve credit to the financial firms with the greatest demand for liquidity. ${ }^{17}$

Policy entered a new phase in September 2008, when the Fed's rescue operations and later its large purchases of U.S. Treasury and agency debt and mortgage-backed securities caused the

\footnotetext{
17 Thornton (2009a) notes that the Fed's initial attempt to satisfy heightened liquidity concerns without increasing the monetary base contrasted with its use of open market operations to increase the monetary base sharply at the century date change (Y2K) in December 1999 and following the terrorist attacks on September 11, 2001. He argues that the Fed may have been reluctant to increase the monetary base to better control the federal funds rate or because Fed officials viewed targeted credit allocation as a more effective means of encouraging banks to lend and avoid selling illiquid assets.
} 


\section{Figure 3}

\section{Monetary Base and M2 Growth (2007-09)}

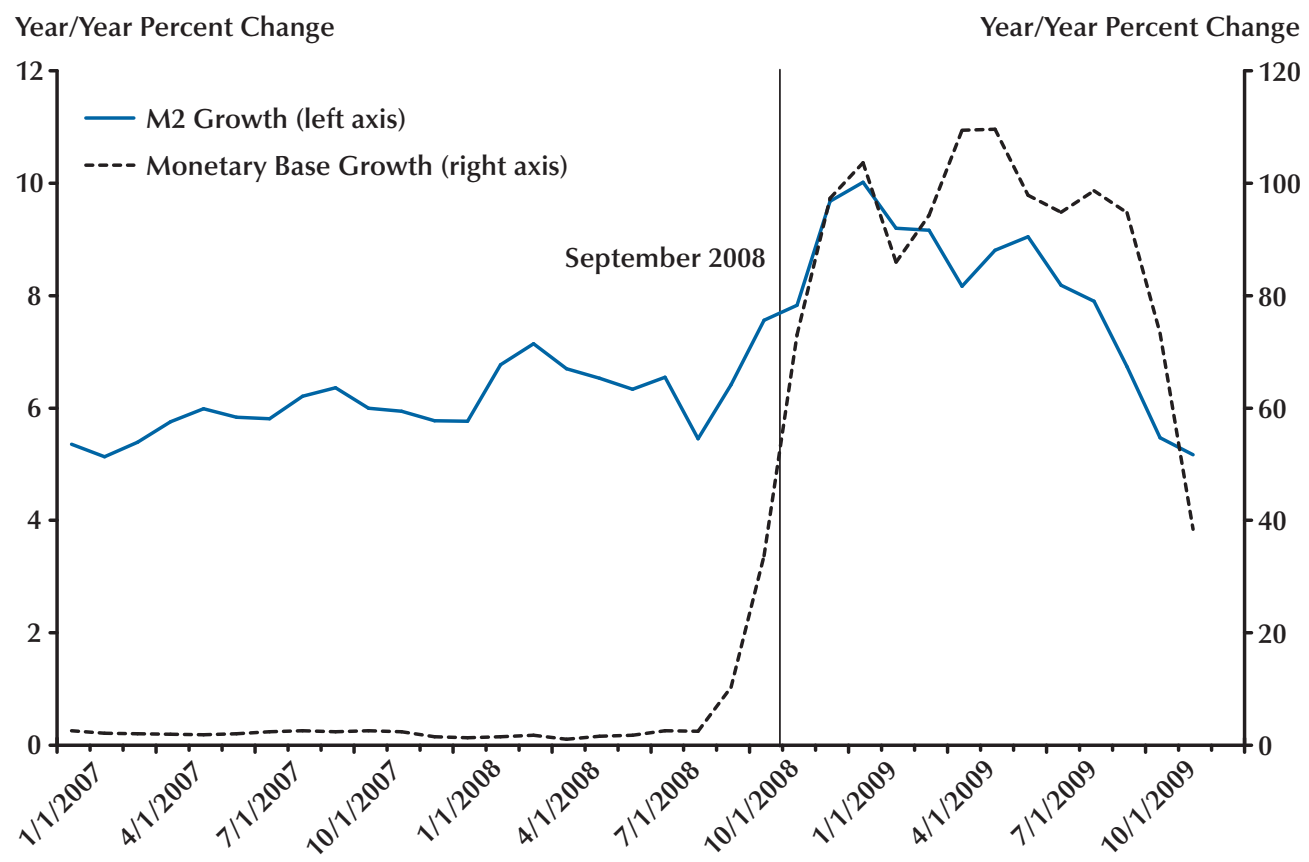

System's total assets and the monetary base to more than double in size. However, the Fed's objective in purchasing mortgage-backed securities was to reduce mortgage interest rates and promote recovery of housing markets, rather than simply to increase the total amount of credit available to the financial system. Nonetheless, the program helped to increase the growth of broader monetary aggregates and thereby likely reduced the risk of deflation.

\section{THE FED'S RESPONSE TO THE CRISES OF 1929-33}

The Federal Reserve's response to the financial crisis and recession of 2007-09 was markedly more aggressive than the Fed's anemic response to the Great Depression. The Fed's policy failures during the Great Depression are legendary. The Fedspecifically, the Federal Reserve Bank of New York-reacted swiftly to the October 1929 stock market crash by lowering its discount rate and lending heavily to banks. However, the Fed largely ignored the banking panics and failures of 1930-33 and did little to arrest large declines in the price level and output. This section reviews Federal Reserve policy during the Great Depression and discusses prominent explanations for the Fed's behavior.

\section{Fed Policy from the Stock Market Crash to Bank Holiday}

Figure 4 shows the level and composition of Federal Reserve credit during 1929-34, providing one measure of the Fed's response to the major financial crises of the Great Depression. ${ }^{18}$ Following the stock market crash, the Federal Reserve Bank of New York used open market purchases

\footnotetext{
${ }^{18}$ In recent years, Federal Reserve credit has been by far the largest component of Federal Reserve assets. However, before World War II, the Federal Reserve Banks held significant gold reserves and other assets aside from Federal Reserve credit. Hence, for the Great Depression period, we present data on Federal Reserve credit, rather than total assets, for better comparison with policy during the recent financial crisis.
} 


\section{Figure 4}

\section{Federal Reserve Credit (1929-34)}

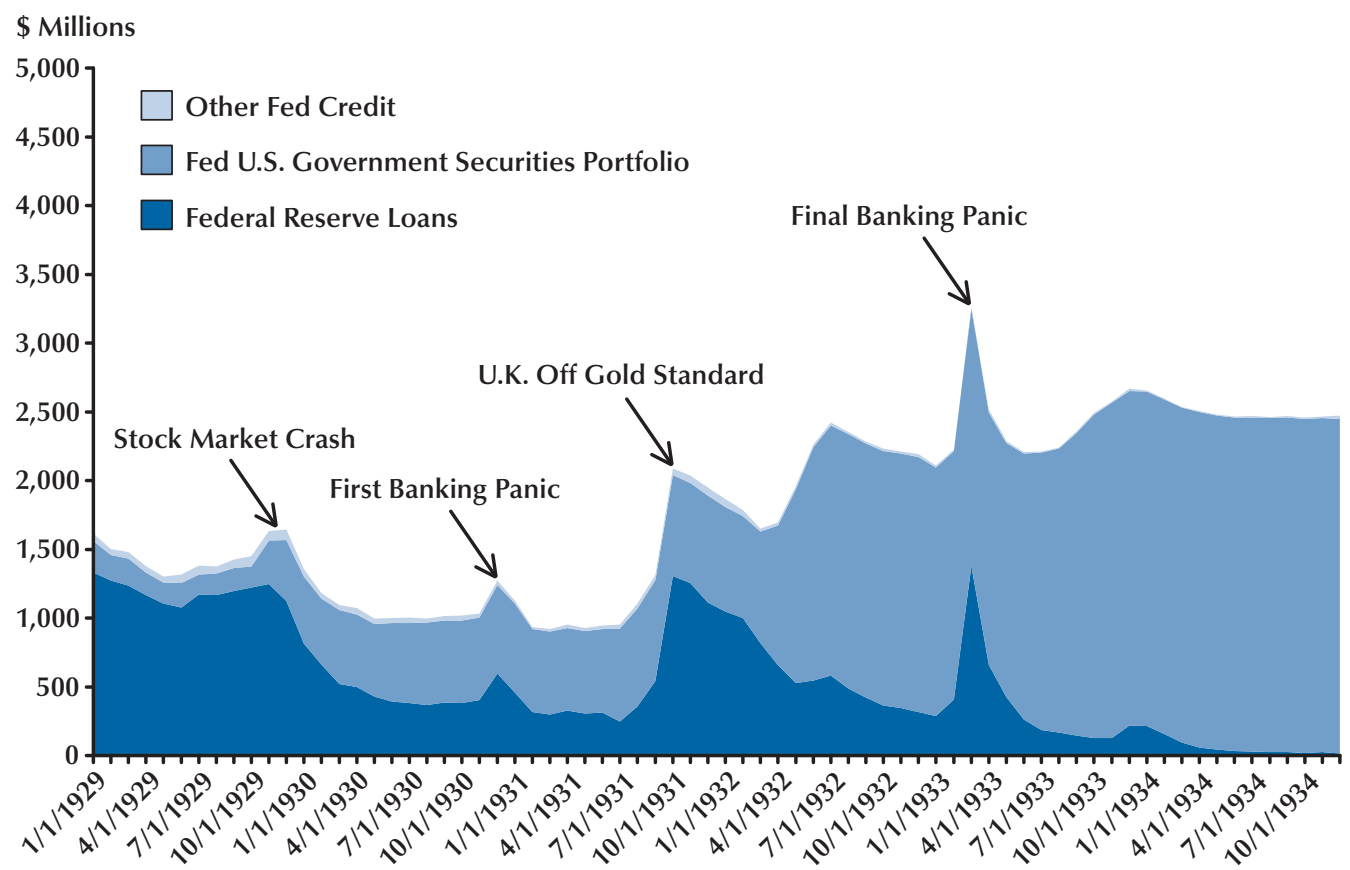

SOURCE: Board of Governors of the Federal Reserve System (1943, pp. 369-71).

and liberal discount window lending to inject reserves into the banking system, which enabled New York City banks to absorb a large amount of loans made by securities brokers and dealers. The New York Fed's actions were "timely and effective" in containing the crisis and preventing widespread panic in money markets and among bank depositors (Friedman and Schwartz, 1963, p. 339). The Federal Reserve Board reluctantly approved the New York Fed's actions ex post, but many members expressed displeasure that the New York Fed had acted independently.

The New York Fed pressed for additional easing in early 1930. However, the Federal Reserve Board rejected several requests for discount rate cuts and additional open market purchases. As Figure 4 shows, total Federal Reserve credit fell by about one-third during the first half of 1930 , mainly because of declines in discount window loans and Fed purchases of bankers' acceptances. ${ }^{19}$ As Figure 5 shows, the monetary base and broader measures of the money stock mirrored Federal Reserve credit outstanding-increasing sharply after the stock market crash but then falling with the decline in Fed credit during 1930. Friedman and Schwartz (1963) contend that the decline in the money stock was the main cause of the subsequent decline in economic activity. ${ }^{20}$

The stock market crash was the first in a series of financial shocks during the Great Depression. Friedman and Schwartz (1963) identify major banking panics in the fourth quarter of 1930, early 1931, fourth quarter of 1931, and in FebruaryMarch 1933. As Figure 4 shows, total Federal

19 Data for "Federal Reserve loans" in Figure 4 are for the sum of discount window loans and bankers' acceptances held by Federal Reserve Banks (which are referred to as "bills bought" in Banking and Monetary Statistics, 1914-41 [BOG, 1943]).

${ }^{20}$ Friedman and Schwartz's (1963) monetary explanation of the Great Depression is widely, but not universally, shared among economists. See Parker (2007) for a survey of alternative views on the causes of the Great Depression. 


\section{Figure 5}

\section{Federal Reserve Credit and the Monetary Aggregates}

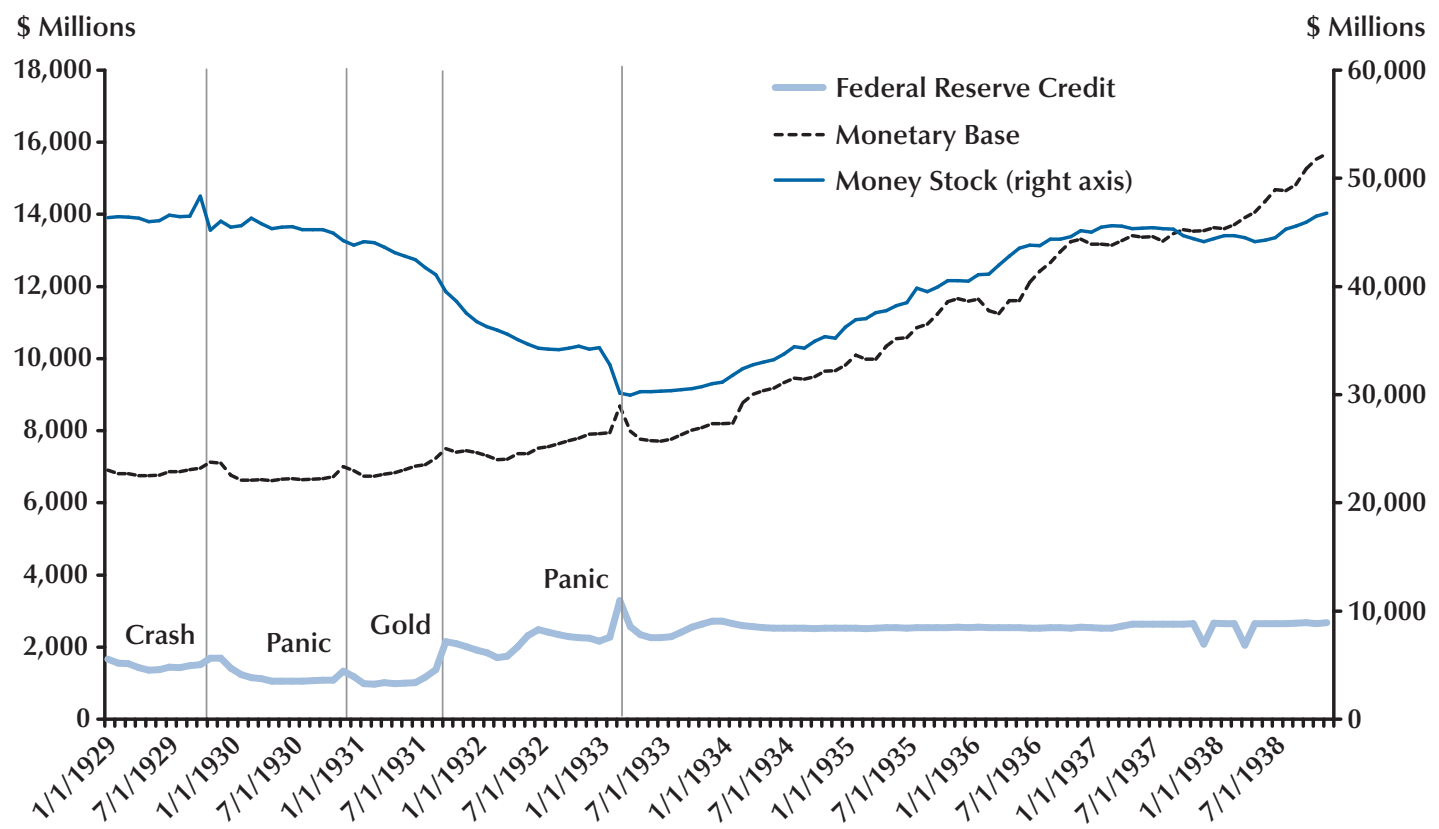

SOURCE: Federal Reserve credit (see Figure 4); St. Louis adjusted monetary base (FRED; http://research.stlouisfed.org/aggreg/ newbase.html); money stock (Friedman and Schwartz, 1963; Appendix A, Table A-1).

Reserve credit surged briefly following the stock market crash and during the banking panics of October-December 1930, September-December 1931 (which followed the United Kingdom's decision to leave the gold standard), and JanuaryMarch 1933. On each occasion, the increase in Federal Reserve credit (and its impact on the monetary base) was quickly reversed. Moreover, as Figure 5 shows, when Federal Reserve credit finally began to grow in 1932, it only temporarily halted the decline in the broader money stock. This pattern is in marked contrast with the behavior of Federal Reserve credit and the monetary aggregates in 2008-09. Although the Fed did not increase the monetary base significantly until September 2008, the broader monetary aggregates continued to grow and the price level continued to rise, albeit slowly, throughout the financial crisis. ${ }^{21}$ In addition, the monetary base rose sharply in the final four months of 2008 and remained large throughout 2009 (see Figure 2).
Why did the Fed permit its credit to contract after each financial shock of 1929-33? Meltzer (2003) argues that Fed officials misinterpreted the signals from money market interest rates and discount window borrowing. Consistent with guidelines developed during the 1920s, during the Depression, Fed officials inferred that low levels of interest rates and borrowing meant that monetary conditions were exceptionally easy, and that there was no benefit-and possibly some risk-from adding more liquidity. Federal Reserve Bank of New York Governor Benjamin Strong explained the use of the level of discount window borrowing as a guide to policy as follows:

${ }^{21}$ Although not apparent in the year-over-year growth rate shown in Figure 3, M2 growth slowed markedly between mid-March 2008 and mid-September 2008, which Hetzel (2009) contends is evidence of a tightening of monetary policy, along with the lack of any reduction in the FOMC's federal funds rate target between April 30 and October 8, 2008. 
Should we go into a business recession while the member banks were continuing to borrow directly 500 or 600 million dollars... we should consider taking steps to relieve some of the pressure which this borrowing induces by purchasing government securities and thus enabling member banks to reduce their indebtedness...As a guide to the timing and extent of any purchases which might appear desirable, one of our best guides would be the amount of borrowing by member banks in the principal centers...Our experience has shown that when New York City banks are borrowing in the neighborhood of 100 million dollars or more, there is then some real pressure for reducing loans, and money rates tend to be markedly higher than the discount rate. On the other hand, when borrowings of these banks are negligible...the money situation tends to be less elastic and if gold imports take place, there is liable to be some credit inflation, with money rates dropping below our discount rate. When [New York City] member banks are owing us about 50 million dollars or less the situation appears to be comfortable, with no marked pressure for liquidation. ${ }^{22}$

Discount window borrowing declined sharply, from $\$ 500$ million for all Federal Reserve member banks in January 1930 (\$39 million for New York City banks) to $\$ 231$ million in April 1930 (\$17 million for New York City banks), and \$226 million in July 1930 (\$0 for New York City banks). Fed officials interpreted these declines as indicating that monetary conditions were extremely easy and that no additional stimulus was required. For example, the governor of the Federal Reserve Bank of San Francisco argued in June 1930 that, "with credit cheap and redundant, we do not believe that business recovery will be accelerated by making credit cheaper and more redundant."23 Indeed, some officials described monetary conditions as too easy and argued for a tighter policy. For example, in January 1930, the governor of the Federal Reserve Bank of Minneapolis wrote that "I cannot

\footnotetext{
${ }^{22}$ Presentation to the Federal Reserve Governors' Conference, March 1926 (quoted by Chandler, 1958, pp. 239-40).

${ }^{23}$ Quoted by Chandler (1971, p. 118).
}

see the desirability of further ease of credit. It seems to me money is getting almost 'sloppy.",24 Several Fed officials believed that Federal Reserve credit should be withdrawn whenever economic activity slows. For example, the governor of the Federal Reserve Bank of Philadelphia stated: "We have been putting out credit in a period of depression when it was not wanted and could not be used, and we will have to withdraw credit when it is wanted and can be used." 25

Federal Reserve credit increased temporarily in late 1930, as shown in Figure 4. Federal Reserve credit normally had a distinct seasonal pattern and typically rose in the autumn when loan demand and interest rates tended to rise. However, in December 1930, the Federal Reserve Bank of New York also purchased \$175 million of U.S. government securities and bankers' acceptances to ease the financial market strains after the failure of the Bank of United States. Numerous banks failed throughout the United States between October and December 1930. Most were small banks that were not members of the Federal Reserve System, and thus unable to borrow at the Fed's discount window. ${ }^{26}$ Friedman and Schwartz (1963) note that Fed officials felt no particular responsibility for nonmember banks. However, they argue that the Fed made a critical error in not saving the Bank of United States, which was a midsize New York City bank and a member of the Federal Reserve System. Although the Federal Reserve Bank of New York participated in discussions about a possible merger to save the Bank of United States, those talks broke down when neither the New York Fed nor the New York clearinghouse banks would guarantee $\$ 20$ million of Bank of United States assets (Meltzer, 2003, pp. 323-24). As with the failure of Lehman Brothers in 2008, the Fed and clearinghouse banks elected to let the Bank of United States fail and focus on containing the resulting fallout.

\footnotetext{
${ }^{24}$ Quoted by Chandler (1971, p. 143).

${ }^{25}$ Minutes of the Open Market Policy Conference, September 25, 1930 (quoted by Chandler, 1971, p. 137). See Chandler (1971) and Meltzer (2003) for information about the policy views expressed by different Federal Reserve officials during the Depression.

${ }^{26}$ Before the Monetary Control Act of 1980, only Federal Reserve member banks had access to the Fed's discount window.
} 
Federal Reserve credit outstanding declined sharply in early January 1931, as money market strains eased. The economic contraction deepened in 1931, deflation took hold, and interest rates and discount window borrowing declined still further. Another wave of bank failures occurred in the first half of 1931, but again most of the banks that failed were nonmember banks located outside New York City and other financial centers. For the first time, banks began to hold excess reserves-that is, reserves in excess of legal requirements. Fed officials took this as further evidence of exceptionally easy monetary conditions and considered engaging in open market sales to "soak up" excess liquidity (Meltzer, 2003, p. 328).

The next major financial shock occurred in late September 1931. After depleting most of its gold and foreign exchange reserves, the United Kingdom abandoned the gold standard on September 21, 1931, and allowed the pound to float freely. Speculation that the United States would soon also leave the gold standard caused large withdrawals of gold and currency from U.S. banks. The Federal Reserve responded by increasing its discount and acceptance buying rates in an attempt to halt and then reverse the gold outflow, and to demonstrate the System's resolve to maintain the gold standard. Federal Reserve officials interpreted their response to the gold outflow as consistent with Bagehot's rule to lend freely at a high interest rate (Meltzer, 2003, p. 348). The Fed did not make significant open market purchases to offset the withdrawal of gold and currency from banks, however, which exacerbated the decline in the monetary aggregates (see Figure 5). Moreover, when gold began to flow back into the banking system, Federal Reserve credit outstanding fell by more than the gold inflow, which resulted in a net decline in total bank reserves. Fed officials apparently were hesitant to make open market purchases because they saw a "disinclination on the part of member banks to use Federal Reserve credit for the purpose of extending credit to their customers." 27

\footnotetext{
${ }^{27}$ Federal Reserve Bank of New York Governor George Harrison
} (quoted by Meltzer, 2003, p. 350).
Besides doubting that open market purchases would serve any useful purpose, at least some Fed officials were concerned that large open market purchases would threaten the System's gold reserves. Although researchers subsequently have concluded that the Fed did have sufficient gold reserves (e.g., Friedman and Schwartz, 1963), Fed officials may have been concerned that large open market purchases would have touched off a resumption of gold outflows (Wicker, 1966). In any event, the excuse became moot when Congress enacted legislation in February 1932 that enabled the Fed to use U.S. government securities as collateral for Federal Reserve notes. ${ }^{28}$ Under pressure from Congress, the Fed then purchased some $\$ 1$ billion of government securities between February and August 1932.

Discount window loans totaled $\$ 848$ million when the Fed began to purchase government securities in February 1932 and, hence, monetary conditions were tight according to the Fed's traditional policy guide. Discount window borrowing declined and banks began to accumulate substantial excess reserves as the Fed continued its purchases. Several Fed officials interpreted the increase in excess reserves as indicating that the Fed's purchases had little benefit. The Fed ended its purchases when discount window borrowing fell to the level it had been before Britain left the gold standard. Nonetheless, the purchases caused Federal Reserve credit to rise substantially (see Figure 4), which for a few months arrested the decline in the money stock (see Figure 5).

The final and most severe banking crisis of the Depression began in February 1933. Banking panics, marked by heavy withdrawals of currency and gold reserves, swept across the country. The Fed reacted as it had in response to gold outflows in 1931: by increasing its discount and acceptance buying rates. Federal Reserve credit increased sharply in March 1933, as discount window loans rose from $\$ 253$ million on February 8 to $\$ 1.4$ billion on March 8, and the Fed purchased some

\footnotetext{
${ }^{28}$ The Federal Reserve Act required each Reserve Bank to maintain gold reserves equal to 40 percent of its note issue and reserves in the form of gold or other eligible securities (which did not include U.S. Treasury securities) equal to the remaining 60 percent. See Friedman and Schwartz (1963, pp. 399-406).
} 
\$400 million of bankers' acceptances. The Fed also purchased $\$ 100$ million of government securities, but this was far too little to offset the decline in bank reserves caused by currency and gold withdrawals. In response to a request from the secretary of the Treasury for larger purchases of government securities, Federal Reserve governor Eugene Meyer replied that a rise in bond yields was a "necessary readjustment in a market which has been too high" and that "Purchases of Government securities at the present time would be inconsistent from a monetary standpoint." ${ }^{29}$ Instead of supplying additional liquidity to the banking system, the Federal Reserve Board voted to suspend the Fed's gold reserve requirement and to recommend that President Hoover declare a national bank holiday. This action and many others were subsequently taken by President Roosevelt on his first day in office on March 5, 1933.

\section{THE FED'S RESPONSE TO EXCESS RESERVES}

The declaration of a national banking holiday, imposition of a temporary system of deposit insurance, and suspension of the gold standard were among the many actions taken by Roosevelt during his first days in office. Currency poured back into banks as they were reopened, and the money stock began to expand (see Figure 5). The inflow of reserves enabled banks to repay their discount window loans and by mid-1934, banks were almost entirely free of debt to the Fed. Under pressure from the Roosevelt administration, the Fed purchased some $\$ 600$ million of government securities during 1933 (Meltzer, 2003, pp. 436-38) but then made no further purchases until 1937 except to replace maturing issues.

While the Fed sat on its hands, gold inflows caused commercial bank reserve balances to increase rapidly during 1934-36. Banks accumulated substantial excess reserves, which by 1935 comprised more than 50 percent of total reserves. Fed officials viewed excess reserves as a potential source of inflation because they could support a

${ }^{29}$ Quoted by Meltzer (2003, p. 383). rapid increase in bank lending. In 1936, officials decided to increase reserve requirements in three steps from 13 to 26 percent on transactions deposits and from 3 to 6 percent on time deposits. ${ }^{30}$ An alternative means of reducing excess reservesselling securities in the open market-was rejected because by July 1936 the volume of excess reserves ( $\$ 2.9$ billion) exceeded the size of the Fed's securities portfolio ( $\$ 2.4$ billion).

Figure 6 shows the dates of each increase in reserve requirements. The policy was successful in reducing both excess reserves and, as the figure shows, the ratio of excess to total reserves. However, interest rates also rose, money stock growth declined sharply, and in May 1937 the economy entered a recession (the shaded region in the figure represents the recession period). In raising the amount of non-interest-earning reserve balances that banks were required to hold against each dollar of deposits, the hike in reserve requirements encouraged banks to reduce their lending in an effort to reduce deposits, which caused money stock growth to fall. The impact might have been less if the Fed had drained an equivalent amount of reserves by selling securities because the cost of holding deposits would have been unaffected. The impact might still have been large, however, if banks held excess reserves mainly as protection against depositor runs, rather than because they lacked profitable lending opportunities.

For the recent episode, Fed actions since September 2008 intended to alleviate credit market strains and encourage economic recovery have resulted in a large increase in excess reserves. Excess reserves rose from an average of less than 5 percent of total bank reserves during the 5 years ending in August 2008 to more than 90 percent in November 2008 and remained at similar levels through 2009. As in the 1930s, many observers contend that the large increase in excess reserves poses a significant inflation risk. However, the Federal Reserve appears unlikely to increase

\footnotetext{
30 The Banking Act of 1935 permitted the Federal Reserve Board to adjust reserve requirements within broad ranges. Before 1980, reserve requirements applied only to Federal Reserve member banks and varied according to a bank's location. In general, reserve requirements were higher for banks located in larger cities ("central reserve" and "reserve" cities) than in smaller cities and towns ("country" banks).
} 


\section{Figure 6}

\section{Excess Reserves and Money Stock Growth (1929-41)}

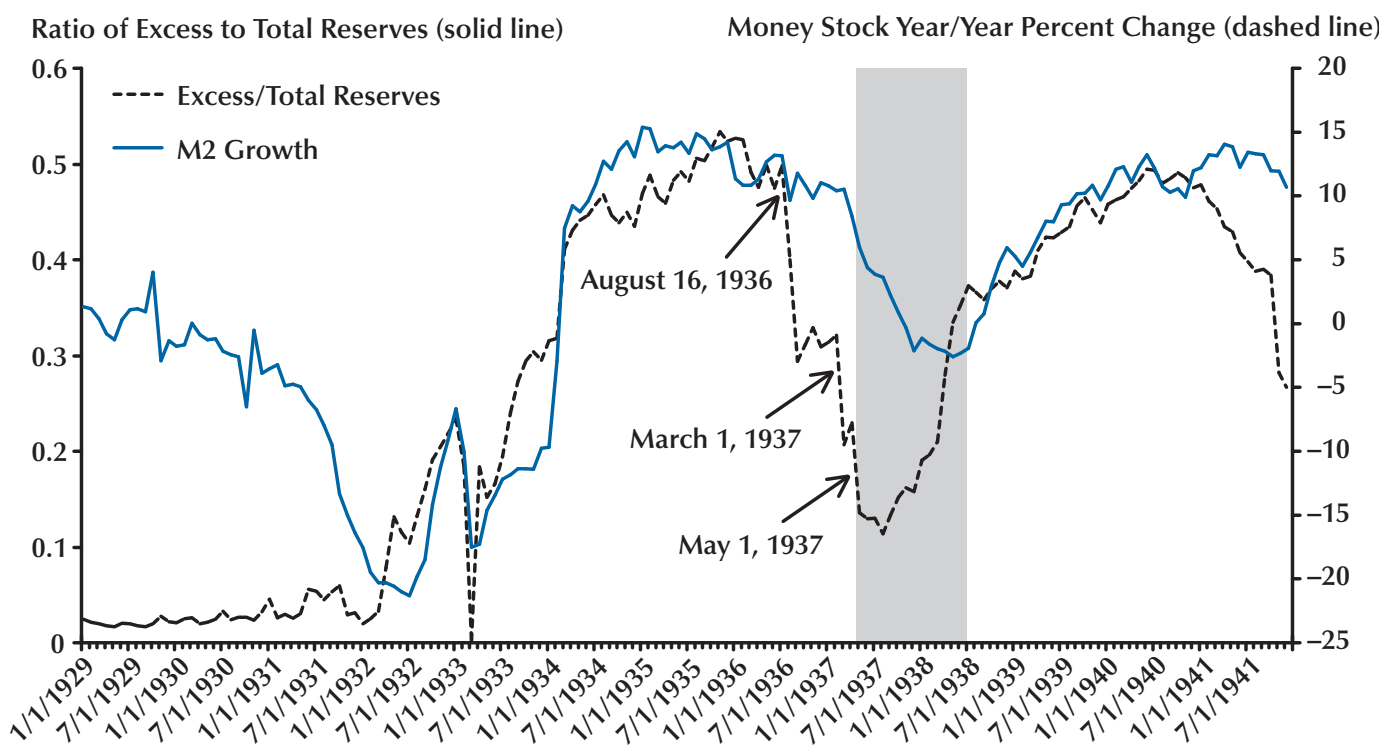

SOURCE: Excess and total reserves (Board of Governors, 1943); money growth (Friedman and Schwartz, 1963; Appendix A, Table A-1).

reserve requirements to reduce excess reserves in the current environment-not because Fed officials are unconcerned about inflation risks, but because the Fed now has other tools to limit the growth in lending associated with a given stock of excess reserves. For example, the Federal Reserve now has the authority to pay interest on banks' reserve balances; in principle, then, the Fed could raise the interest rate high enough to discourage banks from increasing their lending beyond a desirable level. ${ }^{31}$

\section{LESSONS LEARNED?}

The Fed clearly did not repeat many mistakes of the Great Depression during the crisis of 2007-09. The Fed's response to the recent financial crisis was markedly different from, and undoubtedly influenced by, the experience of the Great

${ }^{31}$ Dudley (2009) describes how the Fed could control bank lending by varying the interest rate paid on reserves and other methods that the Fed might use to limit the expansion of bank lending for a given stock of reserves.
Depression. ${ }^{32}$ During the Depression, the Fed permitted the money stock to collapse and a serious deflation to occur. By contrast, the money stock continued to grow, albeit slowly at times, and the price level remained stable throughout the recent crisis.

During the Depression, Fed officials interpreted low levels of discount window borrowing as indicating that banks had no need for additional liquidity. Officials seem to have ignored the possibility that (i) banks were reluctant to borrow due to concern that anxious depositors would interpret a bank's borrowing from the discount window as a sign of weakness or (ii) that many banks were unable to borrow because they lacked eligible collateral (Chandler, 1971, pp. 225-33). By contrast, during the crisis of 2007-09, Fed officials acted quickly to encourage banks to bor-

\footnotetext{
${ }^{32}$ Federal Reserve Chairman Ben Bernanke has authored numerous research papers on monetary conditions and other aspects of the Great Depression. See Parker (2007) for an interview with Chairman Bernanke about his views on the Depression and for references to Bernanke's research on the Depression.
} 
row from the Fed-first by issuing a statement that the discount window was available to meet the liquidity needs of banks, then by reducing the primary credit rate and increasing the maximum term of discount window loans, and finally by introducing the TAF to provide an anonymous source of term funds without any of the stigma associated with discount window borrowing.

During the crisis of 2007-09, the Fed also proved willing to provide loans to avoid the bankruptcy of financial firms that posed significant systemic risk. Further, Federal Reserve officials supported the Treasury Department's program to stabilize banks through capital purchases and stress testing. By contrast, with the exception of the New York Fed's massive injection of liquidity following the October 1929 stock market crash, the Fed paid little attention to systemic risks during the Great Depression. ${ }^{33}$

Although the Fed worked to avoid the bankruptcy of Lehman Brothers, Fed officials elected not to make a loan to forestall Lehman's bankruptcy filing. Many analysts believe that Lehman's bankruptcy significantly worsened the financial crisis. Meltzer (2009a,b) argues that this was a "major mistake": "After 30 years of bailing out almost all financial firms, the Fed made the horrendous mistake of changing its policy in the midst of a recession."

During the Depression, the Federal Reserve elected not to save the Bank of United States from failure, which Friedman and Schwartz (1963) contend was a major mistake that worsened the economic contraction. A key difference between the Lehman and Bank of United States events, however, was that the Fed acted swiftly to limit the financial distress caused by Lehman's bankruptcy in 2008, whereas the Fed did little in response to the failure of the Bank of United States or other bank failures during the Great Depression. For example, following Lehman's failure, the Fed provided an $\$ 85$ billion loan to save AIG and established the AMLF to extend non-recourse loans to U.S. depository institutions and bank holding companies to finance their

\footnotetext{
${ }^{33}$ Bullard, Neely, and Wheelock (2009) describe the problem of systemic risk in financial markets and the recent financial crisis and discuss proposals to mitigate such risks.
}

purchases of asset-backed commercial paper from money market mutual funds, which were under pressure from anxious depositors.

Another lesson of the Great Depression is how not to reduce bank excess reserves. In the 1930s, the Fed doubled reserve requirements to rein in excess reserves. This led to a sharp decline in monetary growth and a recession. In 2009, by contrast, the Fed seems to have rejected the option of increasing reserve requirements to reduce excess reserves and rather has focused on more flexible options that could be adjusted to market conditions and circumstances in the event that it becomes desirable to slow the growth of bank lending.

The Great Depression makes clear that central banks must not allow banking panics and other financial shocks to contract the money stock and cause deflation. However, the Depression offers little guidance on whether extending loans to specific firms or markets, let alone insolvent firms, is a necessary and effective element in the role of lender of last resort. Some economists argue that central banks should supply liquidity mainly, if not exclusively, through open market operations in government securities and not attempt to allocate credit through targeted lending to specific firms or markets (e.g., Goodfriend and King, 1988; Schwartz, 1992). During the Depression, the Fed neither made sufficient open market operations to prevent a collapse of the money stock or deflation nor lent significantly to distressed financial institutions.

Throughout the financial crisis of 2007-09, the Fed sought to alleviate credit market strains by supplying liquidity to affected firms and markets in an effort to reduce risky lending rates and restart "frozen" markets. The Fed focused on "the mix of loans and securities that [the Federal Reserve] holds and on how this composition of assets affects credit conditions for households and businesses," according to Chairman Bernanke (2009a), because "to stimulate aggregate demand in the current environment, the Federal Reserve must focus its policies on reducing [credit] spreads and improving the functioning of private credit markets more generally."

Some observers contend that the Fed's efforts to alleviate the financial crisis and stimulate the 
economy by channeling credit to specific firms and markets were less effective than a policy aimed at rapidly expanding the monetary base. ${ }^{34}$ Critics point to a decline in money stock growth in mid-2008 as evidence that policy was too tight and argue that the recession would have been less severe if the Fed had expanded the monetary base sooner (e.g., Hetzel, 2009; Thornton, 2009b).

Other critics worry that the Fed's lending to specific firms and to support particular markets may have adverse long-term consequences. For example, such lending may have weakened the incentives for creditors to monitor and penalize

\footnotetext{
${ }^{34}$ For example, Taylor and Williams (2009) find little evidence that liquidity provided through the Fed's TAF lowered interest rate risk spreads. McAndrews, Sarkar, and Wang (2008), however, conclude that the TAF eased credit market strains.
}

excessive risk-taking by firms deemed "too big to fail” (e.g., Buiter, 2009; Lacker, 2009; Reinhart, 2008). ${ }^{35}$ Some argue that targeted lending also threatens the Fed's political independence, which is crucial to pursuing a stable monetary policy (e.g., Lacker, 2009; Poole, 2009). Thus, while the Federal Reserve did not repeat the disastrous policies of the Great Depression during the crisis of 2007-09, it remains unclear whether an alternative policy would have been more effective at alleviating the financial crisis and limiting its impact on the broader economy with potentially fewer long-term consequences.

${ }^{35}$ Fed officials acknowledge the problems of too-big-to-fail policies, but contend that without another means of resolving the failures of firms that pose systemic risk, policymakers had little choice but to protect creditors from taking losses to avoid catastrophic consequences for the financial system and economy (e.g., Bernanke, 2009b).

\section{REFERENCES}

Bernanke, Ben S. "Nonmonetary Effects of the Financial Crisis in Propagation of the Great Depression." American Economic Review, June 1983, 73(3), pp. 257-76.

Bernanke, Ben S. "Financial Regulation and Financial Stability." Speech at the Federal Deposit Insurance Corporation's Forum on Mortgage Lending for Low and Moderate Income Households, Arlington, Virginia, July 8, 2008a; www.federalreserve.gov/newsevents/speech/bernanke20080708a.htm.

Bernanke, Ben S. "U.S. Financial Markets.” Testimony before the Committee on Banking, Housing, and Urban Affairs, U.S. Senate, September 23, 2008b; www.federalreserve.gov/newsevents/testimony/bernanke20080923a1.htm.

Bernanke, Ben S. "The Crisis and the Policy Response.” The Stamp Lecture, London School of Economics, London, England. January 13, 2009a; www.federalreserve.gov/newsevents/speech/bernanke20090113a.htm.

Bernanke, Ben S. "Financial Reform to Address Systemic Risk." Remarks at the Council on Foreign Relations, Washington, DC, March 10, 2009b; www.federalreserve.gov/newsevents/speech/bernanke20090310a.htm.

Bernanke, Ben S. "Reflections on a Year of Crisis.” Remarks at the Federal Reserve Bank of Kansas City's Annual Economic Symposium, Jackson Hole, Wyoming, August 21, 2009c; www.federalreserve.gov/newsevents/speech/bernanke20090821a.htm.

Board of Governors of the Federal Reserve System. Banking and Monetary Statistics, 1914-1941. Washington, DC: Board of Governors, 1943; http://fraser.stlouisfed.org/publications/bms/.

Board of Governors of the Federal Reserve System. Press release, August 10, 2007; www.federalreserve.gov/newsevents/press/monetary/20070810a.htm.

Board of Governors of the Federal Reserve System. Press release, September 16, 2008a; www.federalreserve.gov/newsevents/press/other/20080916a.htm.

Board of Governors of the Federal Reserve System. Press release, September 19, 2008b; www.federalreserve.gov/monetarypolicy/20080919a.htm. 


\section{Wheelock}

Board of Governors of the Federal Reserve System. Press release, September 21, 2008c; www.federalreserve.gov/newsevents/press/bcreg/20080921a.htm.

Board of Governors of the Federal Reserve System. Press release, October 7, 2008d; www.federalreserve.gov/newsevents/press/monetary/20081007c.htm.

Board of Governors of the Federal Reserve System. Press release, October 21, 2008e; www.federalreserve.gov/monetarypolicy/20081021a.htm.

Board of Governors of the Federal Reserve System. "Joint Statement by Treasury, Federal Reserve, and the FDIC on Citigroup.” Press release, November 23, 2008f; www.federalreserve.gov/newsevents/press/bcreg/20081123a.htm.

Board of Governors of the Federal Reserve System. Press release, November 25, 2008g; www.federalreserve.gov/newsevents/press/monetary/20081125b.htm.

Brunnermeier, Markus K. “Deciphering the 2007-08 Liquidity and Credit Crunch.” Journal of Economic Perspectives, Winter 2009, 23(1), pp. 77-100.

Buiter, Willem. “The Fed’s Moral Hazard Maximising Strategy.” March 6, 2009; http://blogs.ft.com/maverecon/2009/03/the-feds-moral-hazard-maximising-strategy/.

Bullard, James; Neely, Christopher J. and David C. Wheelock. "Systemic Risk and the Financial Crisis: A Primer." Federal Reserve Bank of St. Louis Review, September/October 2009, 91(5, Part 1), pp. 403-18; http://research.stlouisfed.org/publications/review/09/09/part1/Bullard.pdf.

Chandler, Lester V. Benjamin Strong, Central Banker. Washington, DC: Brookings Institution, 1958.

Chandler, Lester V. American Monetary Policy, 1928-1941. New York: Harper and Row, 1971.

CBS News. “Ben Bernanke’s Greatest Challenge.” 60 Minutes interview, March 15, 2009; www.cbsnews.com/stories/2009/03/06/60minutes/main4862191.shtml.

Dudley, William C. “The Economic Outlook and the Fed’s Balance Sheet: The Issue of 'How' versus 'When.”, Remarks at the Association for a Better New York Breakfast Meeting, New York, July 29, 2009; www.newyorkfed.org/newsevents/speeches/2009/dud090729.html.

Fettig, David. “The History of a Powerful Paragraph.” Federal Reserve Bank of Minneapolis The Region, June 2008, pp. 33-34; www.minneapolisfed.org/publications papers/pub display.cfm?id=3485.

Friedman, Milton and Anna J. Schwartz. A Monetary History of the United States, 1867-1960. Princeton, NJ: Princeton University Press, 1963.

Goodfriend, Marvin and Robert G. King. "Financial Deregulation, Monetary Policy, and Central Banking." Federal Reserve Bank of Richmond Economic Review, May/June 1988, pp. 3-22; www.richmondfed.org/publications/research/economic review/1988/pdf/er740301.pdf.

Gorton, Gary. "Slapped in the Face by the Invisible Hand: Banking and the Panic of 2007." Prepared for the Federal Reserve Bank of Atlanta’s 2009 Financial Markets Conference: Financial Innovation and Crisis, May 11-13, 2009; www.frbatlanta.org/news/CONFEREN/09fmc/gorton.pdf.

Hackley, Howard H. Lending Functions of the Federal Reserve Banks: A History. Washington, DC: Board of Governors of the Federal Reserve System, 1973; http://fraser.stlouisfed.org/publications/lffrs/issue/4944/download/79371/lendfunct hackley1973o.pdf.

Hetzel, Robert L. "Monetary Policy in the 2008-2009 Recession.” Federal Reserve Bank of Richmond Economic Quarterly, Spring 2009, 95, pp. 201-33; www.richmondfed.org/publications/research/economic quarterly/2009/spring/pdf/hetzel2.pdf. 
Lacker, Jeffrey M. "Government Lending and Monetary Policy.” Remarks at the National Association for Business Economics, Alexandria, Virginia, March 2, 2009;

www.richmondfed.org/press room/speeches/president jeff lacker/2009/lacker speech 20090302.cfm.

McAndrews, James; Sarkar, Asani and Zhenyu Wang. "The Effect of the Term Auction Facility on the London Inter-Bank Offered Rate.” Federal Reserve Bank of New York Staff Report No. 335, July 2008; www.newyorkfed.org/publications/frame2.cfm?url=http \%3A \% 2F\%2Fwww \%2Enewyorkfed\%2Eorg\% 2Fresearch \%2Fstaff\%5Freports $\% 2$ Fsr335\%2Ehtml.

Meltzer, Allan H. A History of the Federal Reserve, Volume 1: 1913-1951. Chicago: University of Chicago Press, 2003.

Meltzer, Allan H. “What Happened to the 'Depression'?” Wall Street Journal, August 31, 2009a.

Meltzer, Allan H. "Regulatory Reform and the Federal Reserve." Testimony before the Subcommittee on Monetary Policy, House Committee on Financial Services, July 9, 2009b; www.house.gov/apps/list/hearing/financialsvcs dem/meltzer testimony.pdf.

Parker, Randall E. The Economics of the Great Depression: A Twenty-First Century Look Back at the Economics of the Interwar Era. Cheltenham, UK: Edward Elgar, 2007.

Poole, William. “The Bernanke Question.” Cato Institute Commentary, July 28, 2009; www.cato.org/pub display.php?pub id=10388.

Reinhart, Vincent R. “Our Overextended Fed.” Wall Street Journal, March 26, 2008.

Schwartz, Anna J. "The Misuse of the Fed's Discount Window.” Federal Reserve Bank of St. Louis Review, September/October 1992, 74(5), pp. 58-69; http://research.stlouisfed.org/publications/review/92/09/Misuse Sep Oct1992.pdf.

Taylor, John B. and John C. Williams. “A Black Swan in the Money Market.” American Economic Journal: Macroeconomics, January 2009, 1(1), pp. 58-83.

Thornton, Daniel L. “The Fed, Liquidity, and Credit Allocation.” Federal Reserve Bank of St. Louis Review, January/February 2009a, 91(1), pp. 13-22; http://research.stlouisfed.org/publications/review/09/01/Thornton.pdf.

Thornton, Daniel L. "Would Quantitative Easing Sooner Have Tempered the Financial Crisis and Economic Recession?” Federal Reserve Bank of St. Louis Economic Synopses No. 37, August 17, 2009b; http://research.stlouisfed.org/publications/es/09/ES0937.pdf.

Volcker, Paul. Remarks at a Luncheon of the Economic Club of New York, April 8, 2008; http://online.wsj.com/public/resources/documents/volckerspeech040808.PDF.

Wicker, Elmus R. Federal Reserve Monetary Policy 1917-1933. New York: Random House, 1966. 
